\title{
Pribumisasi Islam dalam Konteks Budaya Jawa dan Integrasi Bangsa ${ }^{1}$
}

\author{
Mudhofir Abdullah \\ Dosen Fakultas Syariah dan Ekonomi Islam IAIN Surakarta
}

\begin{abstract}
Abstrak
Islam dan budaya Jawa merupakan tema utama yang menjadi wacana dalam kehidupan Nusantara. Selama berabad-abad lalu ketika Islam datang ke Nusantara, keduanya berdialog dengan kepercayaan lain seperti Hindu, Budhha dan agama lokal lainnya. Kebudayaan Jawa, di sisi lain, merupakan warisan masyarakat Jawa selama ribuan tahun dan terus memperkaya khazanah budaya dunia. Hubungan antara Islam dan Jawa, oleh karenanya, menarik perhatian para peneliti dan telah menghasilkan banyak karya ilmiah. Sepanjang sejarah, hubungan antara Islam dan budaya Jawa tidak selalu berjalan mulus. Ketegangan dan konsensus terjadi di antara keduanya, baik secara jelas terlihat ataupun tidak. Ketegangan tersebut merujuk kepada pribumisasi Islam di Jawa. Pribumisasi Islam di Jawa merupakan proses transformasi saling pinjam antara unsur-unsur luar ke dalam lokalitas Jawa atau sebaliknya. Pribumisasi Islam, oleh karenanya, merupakan artikulasi interaksi sosial budaya Islam dan Jawa. Dalam konteks negara-bangsa, pribumisasi Islam harus naik ke level yang lebih tinggi, untuk mencapai integrasi nasional. Artikel ini membahas pribumisasi Islam dalam konteks budaya Jawa, yang bertujuan untuk membangun integrasi nasional. Diskusi ini berangkat dari gagasan bahwa tidak ada integrasi tanpa integrasi sukusuku, dan tidak ada integrasi bangsa tanpa integrasi pemeluk agama.
\end{abstract}

\begin{abstract}
Islam and the Javanese culture is a major theme which has become the discussion throughout of the archipelago. Centuries ago when Islam came to the archipelago, it was discussed with other great ideas such as Hinduism, Buddhism and the local religions. In contrast, the culture has been the legacy of the Javanese for thousands of years and continues to be enriched by world cultures. The relationship between Islam and the Javanese, therefore, attracted the interest of researchers and produced many academic works. Throughout its history, the relationship between Islam and the Javanese culture was not always harmonious. At times there were tensions and then at
\end{abstract}

${ }^{1}$ Disampaikan dalam Srawung Seni dan Ketuhanan dalam rangka Mangayubagya Dies Natalis XXI IAIN Surakarta, 9 September 2013. 
other moments there was consensus, the phenomenon was open and hidden. Such a paradox is referred to as the indigenization of Islam in Java.

Indigenization of Islam is the transformation process of mutual borrowing between the outside elements and the locality. Indigenization of Islam is the articulation of socio-cultural interaction of Islam within the Javanese culture in the context of the nation-state: Islam must rise to higher levels as a means of achieving national unity. The paper discusses the indigenization of Islam in the context of the nation state.

Keywords: Indigenization of Islam, Javanese culture, transformation, national integration

\section{Pendahuluan}

Istilah pribumisasi Islam dipopulerkan oleh Abdurrahman Wahid (Gus Dur) pada era $1980-\mathrm{an}^{2}$. Tentu saja, istilah pribumisasi secara praksis jauh lebih tua. Dakwah Walisongo di pulau Jawa, misalnya, telah menggunakan kearifan-kearifan lokal dan tradisi sebagai metode. Walisongo tidak seluruhnya menghapus tradisi-tradisi lokal dan menggantinya dengan Islam. Walisongo mempertahankan segi-segi tradisi dan mencoba mengadaptasinya dengan ajaran Islam tanpa merusak nilai substansialnya. Salah satu contoh, bangunan masjid kuno masih mempertahankan model Hindu-Budha pada aspek kubahnya yang bersusun tiga.

Pribumisasi Islam, karena itu, memiliki kaitan langsung dengan sejarah perkembangan Islam di Nusantara dan telah terjadi dalam sejarah yang panjang. Pribumisasi Islam sebagai suatu proses sosio-historis merupakan sebuah keniscayaan. Hal ini demikian karena universalitas Islam memerlukan penjabaran operasional sehingga eksistensinya lebih efektif. Selanjutnya, universalitas tak akan efektif tanpa diikat oleh nilai-nilai lokal. Agar universalitas Islam terasa hadir dan relevan dengan gemuruh kehidupan sosial di bumi, ia perlu diturunkan ke tingkat abstraksi yang sederhana; yang

\footnotetext{
${ }^{2}$ Saya belum menemukan secara pasti kapan ungkapan ini dikemukakan Gus Dur. Tapi ungkapan ini merupakan komentar Gus Dur yang sangat kontroversial di masyarakat waktu itu. Gus Dur, terkait pribumisasi Islam, mengusulkan ucapan assalamu'alaikum diganti dengan selamat pagi atau selamat malam. Tentu saja, substansinya tidak berhenti di situ. Misi Gus Dur adalah bagaimana Islam yang universal dapat relevan dengan lokalitas. Lihat Abdurrahman Wahid, "Pribumisasi Islam" dalam Muntaha Azhari dan Abdul Mun'im Shaleh, edit., Islam Indonesia Menatap Masa Depan (Jakarta: P3M, 1989).
} 
mudah dimengerti oleh akal; dan agar menjadi pedoman hidup praksis bagi manusia. Dari argumen inilah, pribumisasi Islam menemukan maknanya.

Persoalannya, apakah istilah pribumisasi Islam masih relevan dengan tantangan-tantangan modern yang jauh lebih rumit? Bagaimanakah pribumisasi Islam dilakukan tanpa merusak "tatakrama" atau kaidah baku Islam? Dan bagaimana meletakkan Islam dalam cangkang budaya Jawa yang eksistensinya dipenuhi peradaban silang antara Animisme-Hindu-Budha yang jauh lebih tua dan lebih dulu ada? Bagaimana pula hubungan pribumisasi Islam dan harmoni budaya bagi terciptanya integrasi bangsa? Pertanyaanpertanyaan di atas akan dicoba bahas dan diperdebatkan dalam perspektif historis-antropologis.

Penting dicatat bahwa tiga topik utama, yakni: pribumisasi Islam, budaya Jawa, dan integrasi bangsa memiliki kaitan erat. Pribumisasi adalah suatu proses atau transformasi unsur-unsur asing dengan unsur-unsur lokal. Ada potensi konflik dalam hubungan antara ketiganya. Karena itu, menelisik Islam dan budaya Jawa dalam konteks negara-bangsa menjadi sangat penting guna menemukan potensi konflik dan konsensus. Selanjutnya, potensipotensi tersebut dapat dipakai sebagai instrumen integrasi bangsa melalui kecakapan mengelola konflik menjadi konsensus. Jadi, pribumisasi Islam dalam budaya Jawa bukan dipandang sebagai proses "meluruhnya" budaya Jawa ke dalam Islam, tapi sebuah proses "beri dan terima" antara keduanya dalam pengertian akulturasi menuju integrasi bangsa.

Pendekatan historis-antropologis akan digunakan untuk menelisik hubungan antara pribumisasi Islam, budaya, dan integrasi bangsa. Sejak meluasnya karya E.B. Tylor Primitive Culture ${ }^{3}$ dan J.G. Frazer The Golden Bough $^{4}$ ke masyarakat, agama telah menjadi fokus utama teori antropologi. Di antara masalah-masalah utama dalam diskusi antropologi mengenai agama adalah tentang sifat, asal-usul kepercayaan keagamaan, hubunganhubungan logis dan historis antara mitos, kosmologis, dan ritual; serta antara

\footnotetext{
${ }^{3}$ E. B. Tylor, Primitive Culture (London: J. Murray, 1891). Arti penting karya Tylor terletak pada apresiasinya terhadap konteks sejarah dan agama. Primitive Culture dipublikasikan kepada masyarakat Inggris di saat kaum agamawan sedang menghadapi tantangan-tantangan yang dapat merusak keyakinan mereka. Tylor juga menerapkan gaya baru dalam penelitiannya. Ia lebih menekankan pada "etnografi" dan "etnologi". Lebih lanjut lihat Daniel L. Pals, Seven Theories of Religion (New York, Oxford: Oxford University Press, 1996), h. 18, 19, 20.

${ }^{4}$ J.G. Frazer, The Golden Bough: A Study in Magic and Religion (New York: The Macmillan Com.: 1924).
} 
agama dan ranah kebudayaan lain. Pribumisasi Islam adalah soal cara agama ini diadaptasi ke dalam lokalitas oleh para agen. Sementara budaya Jawa adalah suatu campuran antara animisme, Hindu, Budha, dan keperyaankepercayaan lain yang telah lama ada. Saling pengaruh antara agama-agama itu kemudian dilihat potensinya di dalam membangun integrasi bangsa.

\section{Menegaskan Pribumisasi Islam}

Mungkin istilah "pribumisasi" merupakan data baru dalam ensiklopedi, jika ada. Dalam konteks Islam, pribumisasi mengacu pada proses terjadinya nilai-nilai Islam pada suatu komunitas warga atau bangsa, tepatnya bangsa non-Arab, misalnya, wong Jawa. Jika demikian, "pribumisasi" -menurut saya- sama dengan transformasi unsur-unsur Islam pada unsur-unsur budaya pribumi. Jika diperluas lagi, pribumisasi adalah kelanjutan dari proses akulturasi budaya. Yakni, sebuah proses di mana unsur-unsur luar diterima oleh unsur-unsur lokal atau sebaliknya.

Jika pribumisasi Islam diletakkan dalam konteks budaya Jawa, maka ia dapat diartikan sebagai suatu proses pertemuan atau saling adopsi antara unsur-unsur Islam dan unsur-unsur lokal Jawa. Dua entitas tidak saling meniadakan, tetapi saling memperkaya. Di sini peran pembawa Islam ke Nusantara, khususnya ke Jawa_para Walisongo-sangat penting. Mereka telah memilih tafsir Islam yang memerhatikan lokalitas. Pemahaman Islam dirujukkan pada konteks-konteks budaya Jawa.

Apa yang dilakukan para pembawa Islam ke Jawa bukanlah sebuah anomali. Para penyebar Islam benar-benar menyadari bahwa Jawa dengan kekayaan tradisi dan peradabannya yang panjang bukanlah blangko kosong. Jawa adalah kenyataan lain yang kekayaan tradisi dan norma-norma hidupnya tidak lebih buruk dari tradisi-tradisi agama. Islamisasi yang terjadi sejak masuk ke Jawa pada sekitar abad ke-15, adalah melalui proses damai dan penuh kearifan. Tak ada perang; tak ada penaklukan; dan tak ada pemaksaan agama di Jawa selama transformasi Islam berlangsung di sini. ${ }^{5}$

\footnotetext{
${ }^{5}$ Ricklefs menolak pendapat bahwa islamisasi di Nusantara termasuk Jawa dilakukan dengan cara damai melalui perdagangan, perkawinan, dan persuasi. Ricklefs bilang, “...Islam was spread in Indonesia not only by persuasion and commercial pressure, but by the sword as welf'. Lihat M. C. Ricklefs, A History of Modern Indonesia since C. 1200, Third Edition (London: Palgrave Macmillan, 2001), 17. Pendapat Ricklefs juga dipersoalkan, misalnya, apakah perang dalam penyebaran Islam di Indonesia sebagai tujuan ataukah hanya artikulasi dari motif-motif ekonomi dan politik para pihak.
} 
Apa artinya? Jawa adalah sebuah lokus yang menjadi atau panci lebur bagi agama-agama dari luar selama ribuan tahun. Secara intrinsik, manusia Jawa adalah sangat terbuka dan menonjolkan pada harmoni. Selama jutaan tahun Jawa menganut agama animisme dan ribuan tahun menganut agama Hindu-Budha, lalu Islam datang disusul Kristen. ${ }^{6}$ Saling memberi dan menerima bagi Jawa dan lainnya sudah terjadi begitu lama sehingga tumbuh sebuah kultur terbuka. Sifat keterbukaan inilah yang menyebabkan budaya Jawa masih terus berevolusi dan terus dimasuki unsur-unsur non-Jawa termasuk nilai-nilai Islam.

Dilihat dari sejarah asal-usul, semua agama di Jawa adalah impor. Hindu berasal dari India, Budha dari India-China, Islam dan Kristen berasal dari Timur Tengah (Arab). ${ }^{7}$ Agama asli dari Jawa adalah "agama" Animisme suatu kepercayaan pada roh-roh dan penguasa-penguasa di luar dirinya. Nah, kenyataan sejarah ini memperkuat bahwa agama di Jawa adalah produk hibrida dari saling silang budaya agama-agama yang datang ke sini. Para islamolog menyebutnya sebagai agama sinkretik. Walisongo menyadari ini

\footnotetext{
${ }^{6}$ Mircea Eliade menyebutkan bahwa agama paling primitif bagi manusia adalah
} animisme. Lihat karyanya The Myth of the Eternal Return, Cosmos and History (New Jersey: Princeton University Press, 1991). Manusia Jawa tertua adalah Homo Soloensis yang ditemukan di Sangiran dan bertarikh sekitar 1,2 juta tahun yang lalu. Ini bisa disimpulkan bahwa manusia Jawa jutaan tahun menganut agama animisme-dinamisme karena agama Hindu-Budha lahir pada sekitar 600 SM dan masuk ke Nusantara pada sekitar 400 M. Rajaraja Hindu-Budha muncul di Nusantara pada sekitar 400 M. Kerajaan Kutai Kartanegara bertarikh 400 M, Kerajaan Mulawarman bertarikh 450 M di Sunda, Kerajaan Keling atau Kalingga bertarikh $530 \mathrm{M}$ di Jepara Jawa Tengah. Raja-raja itu bergelar baptis Hindu-Budha. Demikian pula Sriwijaya, Majapahit, Syailendra, dan lain-lain. Penggunaan bahasa Sansekerta yang berasal dari India juga menjadi kosa kata umum di Jawa Kuno. Menurut P. J. Zoetmoelder yang mengutip Gonda dalam bukunya Sanskrit in Indonesia mengatakan bahwa dalam kamus bahasa Jawa Kuno susunan Joynboll, terdapat 6.790 kata Sansekerta bersama 6.925 kata asli Jawa. Lihat P. J. Zoetmoelder, Kalangwan: A Survey of Old Javanese Literature (The Hague: Martinus Nijhoff, 1974), 7-23.

${ }^{7}$ Nusantara sebagai bagian dari Asia Tenggara merupakan wilayah pengembangan India dan China di jaman kuno. Tak heran jika agama Hindu dan Budha merupakan agama asing yang masuk ke Nusantara, termasuk Jawa. Selama ribuan tahun dua agama ini sangat dominan dan merupakan agama raja-raja di Nusantara dan Jawa. Agama Islam datang ke Nusantara setelah Islam masuk ke India Selatan (Kerala dan Gujarat). Selain itu, para pedagang Arab juga datang ke Jawa dengan membawa agama Islam. Lalu pada jaman kolonialisme Portugis, Inggeris, Belanda, muncul agama Kristen. Jadi, agama-agama itu datang ke Nusantara dan menarik penduduk lokal. Sebagai perbandingan lihat karya Victor T. King \& William D. Wilder, The Modern Anthropology of South-East Asia (Routledge Curzon, 2003) dan John R. Bowen "The Form Culture Takes: A State-of-the field essay on the Anthropology of Southeast Asia", The Journal of Asian Studies, 54: 1047-1078. 
sebagai kenyataan sehingga metode dakwahnya sangat toleran dan menghargai tradisi-tradisi lokal.

Namun demikian, hal ini tidak sepenuhnya diterima sebagai kenyataan. Di titik ini, hingga kini masih terjadi pertarungan antara Islam nominal dan Islam maksimal -istilah untuk menyebut Islam sinkretik dan kaum santri. Varian Islam tradisional dan Islam modernis pun muncul sebagai akibat logis dari kategorisasi di atas. Clifford Geertz, di sisi lain, mempertegas konsep santri, priyayi, dan abangan. ${ }^{8}$ Priyayi adalah kelompok yang dikategorikan Geertz sebagai mewarisi tradisi Hindu-Budha dalam praksis sehari-hari. Sementara abangan adalah kelompok yang kental dengan animismenya yang masih mempercayai roh halus, lelembut, dan makhluk gaib yang bisa memengaruhi nasib. ${ }^{9}$ Hanya kaum santri yang benar-benar dianggap Muslim. Dalam pandangan Geertz, Islam bagi orang Jawa hanyalah lapisan tipis yang membalut mereka.

Tentu saja, pandangan Geertz tidak sepi kritik. Menurut Harsya W. Bahtiar, Geertz salah meletakkan kategori agama ke dalam kategori sosial, terutama varian priyayi. Marshall G. Hogdson, di sisi lain, menganggap pandangan Geertz sangat bias karena ia mendasarkan teorinya pada perspektif kaum modernis. Secara faktual, praktik-praktik Islam dan islamisasi di Jawa oleh Hogdson dianggap sebagai sangat sempurna sehingga dengan sendirinya menutup pandangan-pandangan Geertz yang bias itu. Dalam kata-kata Hodgson "...for one who knowsIslam, his comprehensive data -despite his intention- show how very little has survived from the Hindu past even in inner Java and raise the question why the triumph of Islam was so complete." ${ }^{10}$ Lebih jauh, Zamahsyari Dhofir menggambarkan praktik Islam begitu dalam dilihat dari hubungan-hubungan yang sering di antara varian-varian yang ada. Dhofir, misalnya, memberi contoh tentang seorang priyayi atau abangan yang selalu minta tolong pada kaum santri untuk mendoakan atau untuk menyembelihkan ayam.

Argumen-argumen itu menunjukkan bahwa pribumisasi Islam di Jawa telah berurat berakar dan melahirkan banyak teori. Teori-teori itu memiliki

\footnotetext{
${ }^{8}$ Clifford Geertz, The Religion of Java (Chicago: The University of Chicago Press, 1960), 121

${ }^{9}$ Clifford Geertz, The Religion of Java, 16-17, 19.

${ }^{10}$ Dikutip kembali dari Nurcholish Madjid, "In search of Islamic Root For Modern Pluralism: The Indonesian Experience" dalam Mark R. Woodward, Toward A New Paradigm: Recent Developments in Indonesian Islamic Thought (Tempe, Arizona: Arizona State University, 1996), 94
} 
kelebihan dan kekurangan. Namun secara prinsip, pribumisasi Islam maupun ide-ide besar dunia ke dalam lokalitas Jawa adalah proses alamiah yang tak bisa dihentikan. Proses semacam ini juga terjadi di wilayah lain. Ketika Islam menyebar dan keluar dari cangkang jazirah Arabia, Islam berakulturasi dengan wilayah-wilayah "pendudukan". Afrika, India, Asia Selatan, Eropa, Amerika, Asia Tenggara, dan Australia adalah wialyah-wilayah yang memiliki peradabannya sendiri ketika Islam datang. Artinya, interaksi intelektual antara Islam dan budaya-budaya setempat melahirkan khazanah Islam yang lebih berwawasan. ${ }^{11}$

Perjumpaan Islam dengan wilayah-wilayah lain mencatat dengan gemilang bagaimana tafsir tentang Islam makin kaya. Khazanah sastra, seni, sains, filsafat, hermeneutika, pengobatan, dan teater memperkaya pandangan Islam. ${ }^{12}$ Dalam perjumpaan dengan peradaban Helenisme (Yunani-Romawi) di Abad Pertengahan, Islam mereguk banyak manfaat. Terjadi lompatan peradaban Islam ke seluruh penjuru dunia. Ajaran Islam yang bersumber pada Alquran dan Hadits diperkaya oleh pandangan-pandangan hibrida. Keduanya diterjemahkan dan ditafsirkan ke berbagai bahasa. Dari perjumpaan inilah, Islam oleh Bernard Lewis disebut menjadi "pengantar" bagi lahirnya peradaban Barat modern. ${ }^{13}$

Kenyataan sejarah ini menjadi dasar bagi teori bahwa pribumisasi Islam di Jawa, pada dasarnya, kelanjutan dari proses sejarah di atas. Proses pribumisasi ini berlangsung secara halus dan terjadi dalam waktu yang perlahan. Pribumisasi ini terjadi di level masyarakat maupun di level pusatpusat kerajaan. ${ }^{14}$ Di level masyarakat, pribumisasi berjalan lebih lambat. Sementara di level kerajaan berjalan lebih cepat. Harus diingat bahwa perubahan-perubahan sosial digerakkan oleh kaum elit. Karena itu, keraton di mana raja dan strukturnya berkuasa dapat menentukan serangkaian aturan. Islam di keratonlah yang sesungguhnya menafsirkan Islam dalam kerangka

${ }^{11}$ Lihat F. Rosenthal, The Classical Heritage in Islam (London: Routledge and Kegan Paul, 1975). Juga M. Fakhry, A Short Introduction to Islamic Philosophy, Theology and Mysticism (Oxford: Oneword, 1997, 135-137.

${ }^{12}$ Lihat C.A. Qadir, Philosophy and Science in the Islamic World (London: Croom Helm, 1988), 28.

${ }^{13}$ Abraham S. Halkin, "The Judeo-Islamic Age, The Great Fusion" dalam Leo W. Schwarz, ed., Great Ages and Ideas of the Jewish People (New York: The Modern Library, 1956), 218-219

${ }^{14}$ Sebagai perbandingan baca Darsiti Soeratman, Kehidupan Dunia Keraton Surakarta 1830-1939 (Yogyakarta: Yayasan Untuk Indonesia, 2000). 
budaya Jawa. Tak heran jika tafsir-tafsir keraton tentang Islam sangat dominan dan memengaruhi pandangan dunia masyarakatnya. ${ }^{15}$

Pandangan dunia Keraton tentang Islam ikut memengaruhi persepsi dan kesadaran publik. ${ }^{16}$ Orang awam akan selalu menganggap bahwa itulah tafsir yang benar tentang Islam. Meski di dalam keraton ada ulama yang tugasnya menjadi penasehat raja, para ulama tidak secara langsung menentukan garis-garis praksis kehidupan raja dan keluarganya. Raja dan keraton melaksanakan secara selektif ajaran Islam. Meski mereka bergelar sultan yang diperoleh melalui restu penguasa atau khalifah di Mekah dan berkedudukan sebagai Sayidin Panatagama, mereka hanya melakukan zakat dan puasa, tetapi tidak melakukan salat lima waktu serta tidak tertarik menunaikan ibadah haji ke Mekah. ${ }^{17}$ Fakta ini menunjukkan bahwa Islam dalam tafsir keraton -sebagai pemegang hegemoni makna Islam- telah diadaptasi dengan nilai-nilai Jawa. Tentu saja, praktik ini tidak berlaku pada semua kerabat keraton.

Sejalan dengan nilai-nilai spesifik budaya Jawa sebagaimana dicitrakan keraton, ada benarnya bila Islam di sini bersifat sinkretik meski tidak dalam arti mutlak. Tapi sinkretisme ini tidak hanya terjadi pada agama Islam, juga terjadi pada agama Hindu, Budha, dan Kristen. Warisan sejarah selama berabad-abad tidak seluruhnya luruh. Ada "gagasan abadi" yang tetap ada dalam aliran manusia Jawa meski mereka hidup serta berkembang dengan berbagai anasir luar. Bahkan kalau diamati dengan cermat, agama Hindu-Budha yang selama berabad-abad menjadi agama kerajaan Majapahit, Sriwijaya, Kediri, dan lain-lain sebenarnya bersifat sinkretik. Atau setidaktidaknya hanya dipraktikkan oleh raja dan keluarganya sementara di hati rakyat tetap bersemayam kepercayaan pada pengaruh para leluhur dan rohroh lainnya. ${ }^{18}$

Seperti diketahui bahwa Islam sudah tersebar pada masa Majapahit, terutama di pesisir pantai utara. Raja Hayam Wuruk (1350-1389) dengan

\footnotetext{
${ }^{15}$ Darsiti Soeratman, Kehidupan Dunia Keraton Surakarta, 17.

${ }^{16}$ M.C. Ricklefs menegaskan bahwa Keraton telah dimistiskan sebagai basis penting bagi kekuasaan kerajaan. Ini sebagai pembeda dengan para pemberontak dari kelompok bangsawan tanpa keraton. Karena fungsinya itu, keraton menjadi sumber penafsiran dan sekaligus agen moral yang layak dicontoh rakyat. Bandingkan M. C. Ricklefs, Yogyakarta Under Sultan Mangkubumi 1749-1792: A History of the Division of Java (London: Oxford University Press, 1974), 17.

${ }^{17}$ Darsiti Soeratman, Kehidupan Dunia Keraton Surakarta, 336-340

${ }^{18}$ Dikutip kembali dalam Sartono Kartodirjo, 700 Tahun Majapahit (1293-1993). (Surabaya: Dinas Pariwisata Propinsi Daerah Tingkat I Jawa Timur, 1997), 72.
} 
Mahapatih Gadjah Mada (w. 1364 M) sebenarnya sudah bersentuhan dengan Islam yang disebarkan melalui para pedagang di pelabuhan-pelabuhan. ${ }^{19}$ Hanya saja, sebagai agama pendatang baru, Islam belum unjuk gigi. Islam hidup berdampingan dengan agama Hindu, Budha, dan agama asli Jawa. ${ }^{20}$ Dalam persentuhannya ini, tentu saja, Islam tidak langsung terang-terangan mengajarkan pokok-pokok ajaran. Ada kompromi-kompromi antara Islam dan budaya. Para pemeluk Islam baru adalah mereka yang tadinya beragama Hindu, Budha, dan atau Animisme. Para muallaf itu, tentu saja, tidak seluruhnya meninggalkan tradisi-tradisi lamanya. Adaptasi, akulturasi, dan inkulturasi terus terjadi dan membentuk apa yang Islam di hari ini sebagian besar dipraktikkan di Jawa.

Demikianlah, ketika secara perlahan Islam makin kuat dan mendirikan kerajaan Islam di Demak (1478-1549) yang kemudian merebut Majapahit pada $1478 \mathrm{M}$, Islam telah berpindah menjadi agama kerajaan. Raden Patah yang kemudian menjadi raja Demak adalah putra salah satu keturunan Majapahit yang menikah dengan putri Champa. Bahkan menurut Slamet Mulyana, kerajaan Majapahit yang terakhir sudah menganut agama Islam sebelum akhirnya runtuh. ${ }^{21}$ Meskipun demikian, keruntuhan Majapahit berlanjut pada Mataram Islam dengan praktik-praktik Islam sinkretis.

Jadi, pribumisasi Islam terjadi sejak Islam pertamakali diperkenalkan kepada orang Jawa dan dianut sebagai agama kerajaan. ${ }^{22}$ Pribumisasi Islam adalah tahapan pemahaman orang Jawa tentang Islam. Raja-raja Mataram Islam sejak itu tidak lagi meminta legitimasi pada trah Hindu-Budha, tetapi langsung kepada khalifah di Mekah. Simbol-simbol Islam mulai dibuat untuk memperbesar keabsahan para raja di samping simbol-simbol Jawa. Dalam cerita Babad Tanah Jawa, misalnya, para raja Mataram dikaitkan sebagai

\footnotetext{
${ }^{19}$ Lihat W. P. Groeneveld, Historical Notes on Indonesia and Malaya: Compiled From Chinese Sources (Jakarta: C. V. Bhatara, 1960), 49

${ }^{20}$ Lihat karya S. F. Dale, Islamic Society and the South Asian Frontier: The Mappilas of Malabar 1498-1922 (London: Oxford University Press, 1980).

${ }^{21}$ Selamet Mulyana, Runtuhnya Kerajaan Hindu-Jawa dan Timbulnya Negara-Negara Islam di Nusantara (Yogyakarta: LkiS, 2005).

${ }^{22}$ Ketika Islam diterima sebagian besar orang Jawa, orang-orang Jawa tidak menanggalkan seluruh kearifan budaya Jawa, termasuk adat-istiadatnya. Itulah sebabnya Ricklefs yang mengutip buku Suma Oriental karya pelancong Portugis Tome Pires menyebut Islam Jawa berbeda dengan Islam di Malaya dan Sumatra. Ricklefs menyebut sebagian besar orang Jawa adalah Islam nominal. Lihat M.C. Ricklefs, A History of Modern Indonesia since c. 1200,9
} 
keturunan para Nabi. ${ }^{23}$ Ini bertujuan untuk memberi legitimasi, sehingga bisa menambah kewibawaan.

Tahap demi tahap, tafsir Islam dari keraton mulai mengakumulasi menjadi seperangkat ajaran dan praksis Islam. Pribumisasi Islam, karena itu, terjadi sangat intens di level ini. Apalagi Islam yang dikembangkan di Jawa adalah dimensi tasawuf atau batin, sehingga pemujaan pada simbol-simbol lebih dominan. Dimensi tasawuf atau esoteris Islam lebih mementingkan harmoni antara Tuhan, manusia, dan alam. Sementara dimensi eksoterik atau fikih mementingkan aspek-aspek hukum dan bersifat lebih ketat. Praktik Islam esoteris inilah yang lebih dominan dalam kehidupan keraton.

Dengan demikian, membaca "pribumisasi Islam" hendaknya tidak dari sudut pandang fikih, misalnya apakah secara fikih ini boleh atau tidak boleh. Tetapi memerhatikan pula aspek-aspek esoteris Islam dan simbol-simbol batin budaya Jawa. Sudut pandang ini, menurut saya, lebih adil dan menerobos cangkang kekakuan fikih. Dalam jangka panjang, sudut pandang Islam esoteris dapat menjadi pilar bagi tumbuhnya toleransi, harmoni, dan menciptakan titik-titik temu peradaban.

\section{Pribumisasi Islam Melalui Budaya}

Penyebaran Islam ke Jawa melalui tahap-tahap sosiologis, budaya, dan juga teologis. Ketika Islam masuk dan menyebar ke sini, karena itu, ia tidak berada di ruang kosong. Gugus-gugus nilai, norma-norma, dan tradisi-tradisi Jawa telah berurat berakar dalam jiwa orang-orang Jawa dan Islam menggenapi makna-makna secara lebih kaya. Dengan Keraton sebagai center of excellence dan juga center of social change, penyebaran, pemaknaan, dan pemahaman Islam ikut serta dalam proses yang saya sebut pribumisasi ini.

Keraton pada masanya, pernah menjadi satu-satunya agen perubahan sosial. Tak heran jika, islamisasi massif terjadi dari Keraton. Titik taut nilainilai Jawa dengan Islam lebih terletak di aspek esoterisnya sehingga Islam tasawuf-lah yang paling kental memengaruhi pandangan-pandangan dunia orang Islam Jawa. Menarik untuk dicatat bahwa pendekatan tasawuf, ternyata efektif bagi penerimaan bangsa Jawa untuk menerima Islam. Hal ini terjadi, menurut sejumlah pengamat, karena tasawuf lebih mudah

${ }^{23}$ Lihat Mark R. Woodward, Islam Jawa: Kesalehan Normatif Versus Kebatinan, terj. Khairus salim (Yogyakarta: LkiS, 1990). 
berkompromi, luwes, dan lebih menekankan substansi ketimbang bentuk. ${ }^{24}$ Nah, para ulama sebagai agen perubahan dan atau perantara budaya memainkan peran tepat di dalam mengawinkan tradisi-tradisi lokal dengan tradisi-tradisi Islam. Ini berbeda dengan dimensi fikih yang lebih formal dan legalistik sehingga ada beberapa benturan, meski hal ini lebih banyak "disembunyikan".

Sesungguhnya ada konflik antara pendekatan fikih dan tradisi Jawa. Namun bagi orang Jawa, keselarasan atau harmoni antara jagad gede (makrokosmos) dan jagad kecil (mikrokosmos) sangat menonjol sehingga diupayakan untuk selalu dijaga dengan baik. Upaya ini menemukan bentuknya dalam ungkapan selamet. Orang Jawa memiliki konsep tentang "rasa" yang sangat baik dalam menghadapi benturan-benturan. ${ }^{25}$ Dan nampaknya dalam konteks pribumisasi Islam cara ini sangat berhasil.

Kata selamet, menurut Geertz memiliki makna lengkap dan menjadi pokok nilai Jawa yang terpenting. Kata selamet mewadahi konsep sejahtera, aman, makmur, terlindung dari gangguan bahaya-bahaya alam maupun adikodrati. ${ }^{26}$ Dalam pandangan orang Jawa, kata selamet mewakili keseluruhan cita-cita manusia dalam hubungannya dengan Tuhan dan alam semesta. Dari kata selamet inilah ritual-ritual Jawa muncul dalam wujud, misalnya, tingkeban (ritual hamil tujuh bulan anak pertama), Babaran, Pasaran, Pitonan, dan lain-lain. ${ }^{27}$ Juga upacara saat kematian, perkawinan, panen, dan lain-lain yang pada intinya untuk mencari keselamatan atau selamet.

Pandangan dunia orang Jawa dan Islam pada tahap sosiologis bertemu dalam wujud-wujud budaya. Wali Songo mengadopsi wayang, seni, dan gamelan, dalam penyebaran Islam. Pada waktu itu, cara ini menjadi metode

\footnotetext{
${ }^{24}$ A. H. Johns adalah pendukung utama teori bahwa islamisasi di Indonesia dilakukan dengan pendekatan sufistik. Ini sejalan dengan kejayaan Sufisme di dunia Islam setelah jatuhnya Bagdad ke tangan Mongol pada 1258, dikutip kembali dalam M. C. Ricklefs, $A$ History of Modern Indonesia since c. 1200, h. 16. Lihat juga Deliar Noer, Gerakan Modern Islam di Indonesia 1900-1942 (Jakarta: LP3ES, 1996), cet. Ke-8, h. 21-22. Alwi Sihab, Islam Inklusif: Menuju Sikap Terbuka dalam Beragama (Bandung: Mizan, 1999), 7

${ }^{25}$ Paul Stange mengulas konsep tentang "rasa" dalam pandangan orang Jawa. Dikatakan "rasa" bukan hanya sebuah istilah yang diterapkan pada pengalaman inderawi yang menggiring pada estetika, tetapi juga merupakan sebuah organ kognitif yang digunakan secara aktif dalam praktik mistik. Lihat Paul Stange, Politik Perhatian: Rasa Dalam Kebudayaan Jawa, terj. Tim LkiS (Yogyakarta: LkiS, 1998), 6-7

${ }^{26}$ Periksa Clifford Geertz, The Religion of Java, 30-32

${ }^{27}$ Clifford Geertz, The Religion of Java, 38-40
} 
sangat efektif untuk mengislamkan Jawa. Upacara-upacara yang diselenggarakan Keraton juga terkait erat dengan Islam, misalnya Garebeg. ${ }^{28}$ Ada tiga upacara Garebeg yang dihubungkan dengan agama Islam di Keraton, yakni: Garebeg Mulud jatuh pada 12 Rabiul Awwal, Garebeg Puasa pada 1 Sawal, dan Garebeg Besar jatuh pada 10 Dzulhijjah untuk merayakan Hari Haji. ${ }^{29}$ Dalam upacara Garebeg ini simbol-simbol Islam ditampilkan dan menggambarkan suatu praksis Islam Jawa.

Selain itu, pribumisasi Islam di Jawa juga terjadi pada pemakaian kalender yang merupakan gabungan unsur-unsur Hindu dan Islam seperti Kalender Saka dengan sistem lunar (qamariyah). Nama-nama Arab untuk 12 bulan juga ditampilkan dengan rasa Jawa seperti 1) Suro untuk Asyura (Muharram), 2) Sapar untuk Shafar, 3) Mulud (dikonversi dari bahasa Arab, Maulid), 4) Bakdo Mulud (dikonversi dari ba'dal maulid) untuk Rabỉ'u alTsāni, 5) Jumadil Awal untuk Jumād al-ûlā, 6) Jumadalakhir untuk Jumād alTsāniyah, 7) Rejeb untuk Rajāb, 8) Ruwah (diambil dari kata arwāh, "ruhruh" -karena kepercayaan bahwa ruh-ruh akan dibangkitkan menjelang Ramadhan), untuk bulan Syakban, 9) Poso, untuk Ramadan, 10) Sawal, untuk Syawwāl, 11) Selo (kata Jawa yang berarti "di antara", yakni di antara dua hari besar Islam Id al-Fitri dan Id al-Adhā), untuk Dzûl Qa'dah, dan 12) Besar (kata Jawa yang artinya "besar", yakni bulan berlangsungnya perayaan hari besar Id al-Adhā), untuk bulan Zulhijjah. ${ }^{30}$ Pribumisasi kalender Islam ke dalam kalender Jawa menunjukkan proses-proses budaya dan memberikan makna betapa Islam berenang dalam gelombang air Jawa tanpa tenggelam serta mengalami konflik.

Secara fisik, pribumisasi Islam muncul dalam bentuk bangunan seperti Masjid dengan kubah susun tiga, ornamen batik, dan modifikasi-modifikasi lain yang berbeda dengan Timur Tengah dan atau Islam. Masjid Demak yang merupakan bangunan Masjid dari masa kerajaan Islam pertama di Jawa dengan kubah susun tiga dan juga masjid-masjid kuno lain di Jawa dapat disebut sebagai pribumisasi Islam fisikal. Hal ini penting untuk dicatat karena suatu bangunan fisik tidak muncul tanpa konsep filosofis pendukungnya. Koentjaraningrat menjelaskan bahwa ada tiga tahapan suatu "benda" muncul. Pertama, mentifact yaitu suatu wujud ide, keyakinan,

\footnotetext{
${ }^{28}$ Darsiti Soeratman, Kehidupan Dunia Keraton Surakarta, 141

${ }^{29}$ Darsiti Soeratman, Kehidupan Dunia Keraton Surakarta, 141

${ }^{30}$ Lihat Nurcholish Madjid dalam Mark Woodward, Toward A New Paradigm: Recents Developments in Indonesiam Islamic Thought, 92
} 
filsafat yang mendasari. Kedua, sociofact yaitu sistem sosial dan aktivitas manusia yang dilakukan dalam kehidupan, dan artifact, yaitu wujud benda atau bangunan yang merupakan hasil dari dua tahap sebelumnya. ${ }^{31}$ Dari sudut teori antropologi ini, bangunan-bangunan Masjid dengan meminjam struktur bukan Islam bukanlah dibuat tanpa sadar, tetapi didasarkan pada pertimbangan-pertimbangan matang. Dan ini menegaskan terjadinya pribumisasi Islam dalam wujud artefak. Bahkan bila dicermati lebih dalam, kubah bersusun tiga sebenarnya adopsi dari tradisi Hindu. Kubah bersusun tiga di Jawa hampir mirip dengan bangunan masjid di Kerala, India Selatan. ${ }^{32}$ Dan bangunan susun tiga adalah tradisi Hindu sebagaimana dijumpai dalam bangunan candi baik di India maupun di Nusantara.

Selain itu, makam-makam di Jawa yang memakai kaligrafi Arab; bedug dan kentungan yang terdapat di masjid-mushala; dan bangunan pondok pesantren yang berhiasi Jawa menggambarkan perpaduan antara Islam-Jawa. Bahkan pondok pesantren dengan ruang-ruang belajar dan kamar tidur santri yang dibimbing seorang kyai disebut sebagai pengambilalihan dari padepokan-padepokan Hindu-Budha di masa lalu. Di zaman peradaban Hindu-Budha, Nusantara dikenal sebagai pusat belajar agama. Sriwijaya pernah menjadi pusat ilmu pengetahuan agama Budha yang dikunjungi pengembara dari negeri China, Champa, dan sekitarnya. Pendeta China yang sangat terkenal, I-Tsing pernah tinggal bertahun-tahun untuk belajar agama di sana. Setelah era Islam yang dikembangkan dari kerajaan Malaka, padepokan-padepokan itu ditiru oleh sistem pesantren.

Selanjutnya, pengajaran Alquran dan cabang ilmu Islam lainnya di pesantren diajarkan dengan bahasa Jawa dan kode-kode tertentu yang diilhami oleh konsep-konsep Jawa. Misalnya, pengajian kitab kuning sebutan untuk buku berbahasa Arab tanpa harakāt- melalui sorogan. ${ }^{33}$ Kaidah-kaidah bahasa Arab seperti mubtada' dipakai kata "utawi" dan khabār dipakai kata "iku", dan lain-lainnya. Peminjaman kode-kode pembelajaran bahasa Jawa untuk memahami Alquran dan ilmu turunannya

\footnotetext{
${ }^{31}$ Koentjaraningrat, Metode-Metode Antropologi Dalam Penyelidikan Masyarakat dan Kebudayaan di Indonesia (Jakarta: Penerbit Universitas, 1958), 449-450.

${ }^{32}$ Kesamaan bangunan Masjid di Jawa dengan di Kerala India Selatan oleh sejumlah pengamat dijadikan dasar tentang asal-usul Islam yang diduga disebarkan dari sana, lihat Mark. R. Woodward, Islam Jawa, 79.

${ }^{33}$ Lihat Zamakhsari Dhofir, Tradisi Pesantren: Studi tentang Pandangan Hidup Kyai (Jakarta: LP3ES, 1982), cet. VI, 50.
} 
menunjukkan daya cipta para kyai di dalam memudahkan pengajaran Islam kepada orang Jawa.

Pribumisasi Islam melalui budaya, dengan demikian, tidak mengalami hambatan berarti di sepanjang sejarahnya. Meskipun demikian, sebuah kredit harus diberikan kepada para Wali Songo dan para ulama yang tidak mempertentangkan secara tajam antara Islam dan budaya Jawa. Prestasi mereka terletak pada bagaimana Islam diterjemahkan dengan idiom-idiom Jawa. Dari fakta-fakta sejarah ini, dapat ditegaskan bahwa ternyata ada akarakar toleransi dan keterbukaan antara keduanya: Islam dan budaya Jawa. Kita sulit membayangkan jika sejak awal Islam disebarkan di Nusantara dengan pendekatan Wahabi, pasti akan terjadi benturan-benturan dan ini akan mencitrakan sebuah kekakuan.

Itulah sebabnya, ada hikmah yang dapat dipetik dari pelajaran sejarah perkembangan Islam yang disebarkan dengan pendekatan tasawuf. Inti dari tasawuf adalah akhlak, dan akhlak itu lebih mementingkan substansi daripada kulit. Karena di Jawa telah ada tradisi-tradisi agama sangat panjang dengan karakter harmoni dan keselarasan, maka ajaran Islam tasawuf mudah diterima. Bahkan diterima dengan tangan terbuka. Islam tasawuf ini juga yang banyak menarik para islamolog untuk memberikan kredit karena perannya dalam memoderasi Islam radikal.

Jadi, penerimaan Islam oleh sebagian besar orang Jawa hanyalah menunggu waktu saja. Kearifan masyarakat Jawa telah siap sejak lama untuk dimasuki agama yang mementingkan keselarasan antara Tuhan, manusia, dan alam. Ini hampir sama miripnya dengan penerimaan masyarakat Madinah atas Islam yang dibawa Muhammad saw. Hal ini terjadi karena masyarakat Madinah sudah biasa dengan tradisi agama (di Madinah ada masyarakat Yahudi dan Nasrani) dibandingkan Mekkah.

Membandingkan dua peristiwa di atas, dapat ditegaskan bahwa keberhasilan pribumisasi Islam melalui budaya sangat tergantung pada bagaimana elit-elit intelektual Islam menerjemahkannya ke dalam idiomidiom lokal. Ini memerlukan kecerdasan di dalam memilih suatu pendekatan. Sekali pendekatan itu keliru dipilih maka akan menjadi boomerang dan selanjutnya akan mengalami banyak hambatan. Sejarah telah membuktikan bahwa pendekatan-pendekatan yang kaku dan tidak memerhatikan lokalitas apalagi bertentangan dengan akal sehat akan tergerus dan ditelan sejarah. 
Di Jawa perkembangan Islam pernah mengalami interupsi dengan kasus hukuman mati pada Syekh Siti Jenar oleh pembela ortodoksi. ${ }^{34} \mathrm{Hal}$ ini juga dialami kaum abangan yang dikecam Muslim ortodoks akibat mempraktikkan sinkretisme Islam. Puncak konflik antara santri dan abangan terjadi pada tragedi G 30 S tahun 1965 di mana pembunuhan kaum abangan oleh kaum santri yang berafiliasi pada organisasi-organisasi Islam dilakukan di sejumlah daerah di Jawa. ${ }^{35}$ Dalam konteks sejarah peradaban Islam, juga terdapat contoh bagaimana sekte-sekte radikal seperti khawarij, misalnya, tak dapat berkembang dalam sejarah dan mati muda. Ini pelajaran penting yang telah menjadi bukti. Para ulama di masa lalu, nampaknya, telah mempelajari hukum besi ini sehingga mereka tidak memaksakan ajaran Islam dengan pendekatan legal-formal.

\section{Pribumisasi Islam dan Integrasi Bangsa}

Ketika Islam sudah mengalami pribumisasi, ia tidak lagi dikerangkeng dalam hegemoni tafsir tunggal misalnya tafsir Arabo-centris yang berkarakter budaya Arab. ${ }^{36}$ Sebuah kitab suci, tentu saja, pemaknaannya seringkali dipengaruhi oleh para penafsirnya dan para penafsir itu dipengaruhi oleh lingkungan serta kecenderungan budayanya. Islam yang terpribumisasi, dengan demikian, sangat relevan dengan konteks-konteks budaya Jawa khususnya dan budaya Nusantara pada umumnya.

Sebagai agama mayoritas bangsa, Islam telah menjadi kenyataan hidup dan telah memainkan peran penting dalam perjuangan bangsa. Ini terjadi karena Islam telah ditafsirkan sesuai dengan konteks-konteks kebudayaan

\footnotetext{
${ }^{34}$ Menarik sekali bahwa Sunan Kalijaga yang merupakan satu-sat unya Wali keturunan Jawa (keturunan Majapahit) tidak setuju dengan hukuman mati untuk Siti Jenar yang mempraktikkan mistik. Sunan Kalijaga dalam banyak hal menafsirkan Islam dengan perspektif kearifan-kearifan Jawa yang sebagiannya punya keterkaitan dengan pendekatan Siti Jenar. Lihat Achmad Chodjin, Sunan Kalijaga: Mistik dan Makrifat (Jakarta: Penerbit Serambi, 2013).

${ }^{35}$ M. C. Ricklefs mengikuti Geertz menyebut tragedi G 30 S/PKI sebagai artikulasi dari konflik santri dan abangan. Bahkan Ricklefs dengan sangat yakin menyebut peristiwa ini sebagai titik balik keluarnya kaum abangan dari Islam ke agama lain. Lihat M. C. Ricklefs, "Six Centuries of Islamization in Java" dalam Nehemia Levtzion (ed.), Conversion to Islam (New York: Holmes and Meier Publisher, Inc.: 1979), 100-101.

${ }^{36}$ Adonis sangat cerdas ketika menjelaskan kebudayaan Arab sebagai pemikiran yang berdasarkan teks yang disebut sebagai ats-tsābit (yang mapan). Ats-tsābit lalu dianggap sebagai satu-satunya yang benar bagi teks tersebut dan berdasarkan hal itu ia menjadi otoritas epistemologis. Dalam kerangka argumen ini, Islam dalam bingkai arabo-centris tidak sama dengan Islam dalam arti universal. Lihat Adonis, al-Thābit wa al-Mutahawwil: Bahthun fi alIttib à' wa al-Ibda' Ind al- 'Arab, (1) al-Ușūl, cet. Ke-5. Beirut, Libanon: Dār al-Fikr, 1986.
} 
bangsa oleh para ulama dan kaum intelektual. Pribumisasi Islam yang berjalan baik dalam sejarahnya di Nusantara menunjukkan bahwa ia tak lagi asing dan dapat diterima sebagai bagian organik dari kebudayaan. Islam adalah nilai dan kearifan bangsa. Ia menjadi identitas nasional, meskipun ia tumbuh merayap melalui penafsiran lokal Jawa, Sunda, Melayu, dan Bugis. ${ }^{37}$ Ada banyak contoh bagaimana kata-kata Arab-Islam terserap dalam bahasa Nusantara. Juga adat-istiadat terkait, misalnya, perayaan Maulid Nabi Muhammad di Jawa, Sumatra, Bugis, dan lain-lain. Contoh-contoh akulturasi itu harus diterima sebagai pengayaan dan bukan sebagai bidah.

Lagi-lagi peran kaum intelektual sangat penting dalam transformasi nilai Islam ke nilai lokal atau dari Islam universal ke Islam partikular sukusuku di Nusantara. Dalam konteks ini, Ali bin Abi Thalib pernah berujar, "innamā yunthiquh al-rijāp' (sesungguhnya Alquran berbicara melalui manusia). Artinya, para pembaca teks Alquran sangat berpengaruh di dalam menerjemahkan makna Alquran. Makin luas dan berintegritas para pembaca Alquran, maka maknanya akan luas dan penuh moral. Sebaliknya, makin sempit dan bodoh pembaca Alquran, maknanya akan sempit dan kaku. Jadi, para ulama dan kaum intelektual Muslim perlu terus-menerus mengusahakan tafsir-tafsir Alquran yang kontekstual, lokal, dan mendorong pada integrasi bangsa. Usaha-usaha semacam ini, menurut saya, layak disebut sebagai pribumisasi Islam Nusantara yang, pada gilirannya, akan menopang integrasi bangsa.

Harus diakui bahwa integrasi bangsa tidak semata-mata soal hubungan Islam dan negara, tetapi soal yang lebih kompleks meliputi aspek politik, ekonomi, sosial, dan budaya. Irwan Abdullah menyebut empat aspek yang menyebabkan disintegrasi sosial, yakni: pertama, kondisi sosial yang bersifat akut yang menggambarkan persoalan penting yang harus ditanggapi, seperti kebodohan dan kemiskinan. Kedua, penyimpangan perilaku yang melawan hukum seperti korupsi, ketidakadilan, kejahatan, dan obat-obatan terlarang. Ketiga, persoalan yang menyangkut disorganisasi yang memperlihatkan rendahnya ketaatan publik terhadap berbagai peraturan dan terhadap sesuatu

\footnotetext{
${ }^{37}$ Sejak Islam masuk ke Nusantara, Alquran sebagai sumber ajaran ditafsirkan oleh para ulama lokal dengan bahasa lokal. Kita mengenal tafsir Alquran berbahasa Jawa, bahasa Sunda, Melayu, dan lain-lain. Ini menunjukkan bahwa dalam tafsir-tafsir itu, secara tak disadari terjadi pribumisasi Islam dan ini mendorong terjadinya transformasi Islam ke dalam perut Nusantara. Karya tentang ini dapat dibaca pada Islah Gusmian, Tafsir Alquran Nusantara: Dari Tradisi, Wacana, Hingga Relasi Kuasa (Yogyakarta: Pustaka Marwa, 2005).
} 
yang bernilai komunal. Keempat, persoalan disfungsi sosial yang menunjukkan tidak berfungsinya lembaga-lembaga sosial dan jaringanjaringan sosial secara meluas. ${ }^{38}$

Meski analisis Irwan Abdullah terkait disintegrasi sosial, namun ini bisa dipakai dalam konteks kebangsaan dan kenegaraan. Faktor-faktor kemiskinan, kebodohan, pelanggaran hukum, salah urus tata kelola pemerintahan, dan lain-lain adalah juga terkait dengan tugas profetik agama Islam. Pribumisasi Islam mengandaikan bahwa ajaran-ajaran Islam itu sampai ke penjabaran operasional sehingga memandu jalannya perilaku-perilaku sosial. Islam harus hadir dalam nilai-nilainya sehingga menciptakan integrasi sosial dan selanjutnya memantapkan integrasi bangsa.

Selanjutnya, integrasi bangsa menuntut pula integrasi antar dan intra umat beragama. Tafsir-tafsir agama sangat menentukan wujud nyata integrasi baik dalam bentuk kerukunan, harmoni sosial, maupun hilangnya pendakuan kebenaran berlebihan para pemeluk agama, utamanya Islam. Tampilnya -meminjam istilah MB. Hooker- "manusia-manusia transisi" 39 semacam Agus Salim, Hatta, Natsir, Harun Nasution, Nurcholish Madjid, Abdurrahman Wahid, dan lain-lain sangat menentukan arah baru Islam dengan sistem teologinya yang lebih terbuka. Gerakan-gerakan terbuka dari para kaum elit tersebut memungkinkan Islam mengalami pribumisasi berkelanjutan sejak ia masuk ke Nusantara. Islam tampil membumi dan bersenyawa dengan budaya-budaya tempatan berkat peran kaum elit intelektual Islam tanpa pertikaian berarti. Bahkan kaum elit Islam -pada masa gerakan kemerdekaan itu- berusaha melakukan usaha-usaha teologispolitis agar Islam tidak berhadap-hadapan dengan kepentingan negara. Hasilnya adalah kesepakatan dan perjanjian luhur berupa Pancasila sebagai dasar negara. ${ }^{40}$ Tentu saja, pencapaian ini sangat sulit dan memerlukan sikap terbuka dengan wawasan-wawasan kebangsaan serta kenegaraan. Wawasan keislaman tidaklah memadai tanpa ditopang oleh wawasan-wawasan kemodernan dengan gagasan besar dunia.

${ }^{38}$ Irwan Abdullah, "Kondisi Sosial yang Dibayangi Disintegrasi Tanpa Ujung" dalam Ninok Leksono (ed.), Indonesia Abad XXI Di Tengah Kepungan Perubahan Global (Jakarta: Penerbit Kompas, 2000), 48-50.

${ }^{39}$ MB Hooker, Islam Mazhab Indonesia: Fatwa-Fatwa dan Perubahan Sosial, terj. Iding Rosyidin Hasan (Jakarta: Penerbit Teraju, 2002), 56.

${ }^{40}$ Baca Ahmad Syafii Maarif, Studi Tentang Percaturan dalam Konstituante: Islam dan Masalah Kenegaraan (Jakarta: LP3ES, 1985), cet. I, 144, 146 
Nah, kaum elit adalah sekelompok manusia yang dengan kecerdasan dan kearifannya menanggapi tantangan-tantangan masa depan melalui penyusunan konsep-konsep utama. ${ }^{41} \mathrm{KH}$. Ahmad Dahlan dengan gerakan Muhammadiyah, KH. Hasyim Asy'ari dengan NU, M. Hatta dan Syafrudin Prawiranegara dengan pemikiran ekonomi Islam, Agus Salim dengan pemikiran sosial budaya, Hazairin dengan pemikiran hukum, dan lainlainnya.

Di era yang lebih kemudian, datang eksponen, seperti Mukti Ali, Harun Nasution, HM. Rasyidi, Nurcholish Madjid, Syafii Maarif, Abdurrahman Wahid, Dawam Rahardjo, Azyumardi Azra, dan lain-lain. Mereka adalah elit-elit intelektual Islam yang dengan ketajaman analisisnya menjawab tantangan-tantangan zaman dengan bahasa kaumnya dan dengan istilah-istilah modern melalui berbagai karya. Karya-karya mereka pada dasarnya adalah tafsir Islam dalam kerangka relevantisasi dengan kontekskonteks zamannya. Konteks-konteks zaman dalam arti ini adalah isu-isu keadilan, pemberdayaan, demokrasi, hak asasi manusia, toleransi, integrasi bangsa, dan lain-lain. Islam tidak lagi dikurung dalam kerangka pemihakan pada kepentingan mazhab dan kelompoknya. Tafsir Islam telah keluar dari cangkang mazhab dan sektarianisme menerobos sekat-sekat. Tema-tema yang diusung pun lebih berkelas, misalnya, tentang nilai-nilai universal yang dimiliki setiap suku dan atau bangsa. Para pemikir Islam itu telah menyadari bahwa kita tak perlu takut dengan perpecahan hanya karena isu-isu pembaharuan. ${ }^{42}$ Tapi, pada saat sama, kaum elit itu bekerja keras mendidik umatnya dengan ajaran-ajaran Islam yang lebih cair dan terbuka melalui strategi kebudayaan, yakni pendidikan.

Penting dicatat bahwa ada garis kebersinambungan antara pribumisasi Islam model Wali Songo di zaman-zaman lampau dengan pribumisasi Islam di masa kini. Tujuan pribumisasi Islam yang disebut pertama adalah membangun integrasi Islam dan budaya lokal dalam kerangka kesatuan umat.

\footnotetext{
${ }^{41}$ Sejarawan terkemuka Arnold J. Toynbee mengemukakan teori tentang challange and respons. Makin besar tantangan, makin besar respons atau tanggapan yang diberikan. Gerak antara tantangan dan tanggapan dari sejumlah elit intelektual itulah suatu peradaban terbangun. Saya meminjam teori Arnold untuk membaca gerakan yang dilakukan manusiamanusia transisi seperti Nurcholish Madjid dan kawan-kawan. Baca lebih lanjut Arnold J. Toynbee, A Study of History (London, New York, Toronto: Oxford University Press, 1956), 7th Edition, Vol. II, 1-3.

${ }^{42}$ Hal ini pernah ditakutkan oleh Nurcholish Madjid pada era 1970-an sebagaimana ditulis dalam papernya berjudul "Pembaruan Pemikiran Islam dan Masalah Integrasi Umat" dibukukan dalam Islam Kemodernan dan Keindonesiaan (Bandung: Penerbit Mizan, 1987).
} 
Sementara di masa kini, pribumisasi Islam bertujuan menciptakan Islam sebagai perekat kesatuan bangsa. Di masa kini, pribumisasi Islam lebih diperlukan untuk merawat hubungan Islam dan negara secara protagonis dengan tafsir-tafsir yang inklusif. Pasang-surut hubungan Islam dan negara di masa Orla dan Orba yang pernah mengancam disintegrasi bangsa harus menjadi pelajaran.

Harus diakui bahwa jasa kaum elit intelektual Islam sangat penting dalam mencairkan hubungan Islam-negara sepanjang masa-masa pembentukannya. Salah satu yang menonjol adalah masalah dasar negara, ide tentang konstitusi, dan hubungan antara agama dan negara. Pancasila sebagai dasar negara dan tafsir atas sila-silanya pernah menjadi perdebatan sengit pada tahun 1950-an sampai akhirnya kembali kepada Dekrit Presiden. Fakta sejarah ini menunjukkan bahwa mempertahankan integrasi bangsa dalam kerangka Negara Kesatuan Republik Indonesia bukanlah pekerjaan ringan. Dibutuhkan keterlibatan kaum elit Islam, elit penguasa, dan elit-elit politik dari beragam latar belakang untuk merumuskan konsensus-konsensus baru yang bersifat integratif.

Itulah sebabnya respons-respons yang tepat dari pemerintah sangat dibutuhkan. Menurut Christine Drake ada tiga kebijakan pemerintah Orde Baru dalam merespon tantangan-tantangan integrasi. ${ }^{43}$ Pertama adalah tanggapan melalui kebijakan pemerintah yang berdimensi budaya melalui pengembangan bahasa Indonesia sebagai bahasa persatuan. Ia dijadikan sebagai bahasa pengantar wajib dalam pendidikan dari sekolah dasar hingga perguruan tinggi. Selain pengembangan bahasa, juga dikembangkan sistem pendidikan yang mewajibkan pengajaran Pancasila dan Pendidikan Kewarganegaraan ke dalam pendidikan nasional. Ini dimaksudkan untuk menanamkan nilai-nilai Pancasila dan kebudayaan nasional kepada anak-anak didik. ${ }^{44}$ Terkait kebijakan terhadap umat Islam sebagai pemeluk mayoritas, pemerintah tidak memperlakukan secara tertutup tetapi secara tepat dan proporsional melakukan komunikasi politik melalui elit-elit Islam. ${ }^{45}$

Kebijakan kedua adalah dari dimensi hubungan. ${ }^{46}$ Sejak tahun 1967 ketika Soeharto menduduki Pejabat Presiden Sementara- memulai

\footnotetext{
${ }^{43}$ Christine Drake, National Integration in Indonesia: Pattern and Policies (Honolulu: University of Hawai Press, 1989), 225.

${ }^{44}$ Christine Drake, National Integration in Indonesia, 226

${ }^{45}$ Bandingkan buku Ahmad Syafii Maarif, Islam dan Masalah Kenegaraan, 144

${ }^{46}$ Christine Drake, National Integration in Indonesia, 232
} 
pembangunan infrastruktur besar-besaran dan bertahap untuk menghubungkan wilayah Nusantara yang luas. Jalan-jalan, televisi, listrik, dan jembatan-jembatan yang strategis dibangun dalam upaya memperbaiki interaksi antara daerah satu dengan daerah lainnya dan dengan pemerintah. Ketiga, kebijakan pembangunan ekonomi. ${ }^{47}$ Pembangunan ekonomi dilakukan dengan Repelita (rencana pembangunan lima tahun) dan dimaksudkan untuk mengurangi kesenjangan antara daerah dan pusat. Secara relatif, selama Orba pembangunan ekonomi berhasil meningkatkan pendapatan negara, tetapi dari sisi pembagian masih menyisakan kesenjangan. Namun begitu, tanggapan pemerintah cukup efektif meredam disintegrasi bangsa untuk kurun waktu yang lama.

Analisis Christine Drake sebenarnya kurang sempurna. Dia tidak banyak mengulas hubungan agama dan negara dari perspektif kaum elit Islam. Menurut saya, perspektif yang disebut terakhir cukup membantu dalam mencairkan ketegangan hubungan Islam dan negara yang dalam sejarahnya mengalami pasang-surut. Doktrin-doktrin Islam tidak lagi dilihat dari perspektif dogmatik, tetapi dilihat dari perspektif kemodernan dan global. Perspektif yang telah keluar dari cangkang teologi ini mendorong perubahan wawasan umat Islam ke arah yang lebih terbuka. Munculnya lembaga-lembaga pendidikan tinggi Islam dan mobilitas kaum santri makin mempercepat perubahan itu. Hasilnya adalah tumbuhnya kelas-kelas masyarakat egaliter, demokratis, inklusif, dan sikap intelektual. Tentu saja, keadaan-keadaan ini memudahkan terjadinya transformasi-transformasi sosio-kultural secara lebih mudah di dalam tubuh umat Islam. Dan umat Islam Indonesia memasuki dunia baru, sebuah dunia yang tidak lagi hidup dalam cangkangnya, tetapi telah berdialog dengan peradaban lain yang lebih kaya.

Namun terburu-buru harus disebutkan bahwa perubahan ini berawal dari lokal, yakni penerimaan Islam oleh pribumi. Lalu beranjak ke komunitas yang lebih luas, yakni Nusantara yang kemudian setelah Indonesia merdeka menjadi Negara-bangsa Indonesia. Dari argumen itu dapat ditegaskan bahwa tak ada integrasi bangsa tanpa integrasi suku-suku bangsa. Tak ada harmoni Islam dan negara tanpa harmoni pemahaman ajaran agama. Juga tak ada moderasi sosial tanpa moderasi ajaran Islam. Dengan hubungan akrab antara Jawa, Islam, dan negara Indonesia maka terjadi keakraban antara hubungan

${ }^{47}$ Christine Drake, National Integration in Indonesia, 237 
ketiganya-meskipun untuk itu diperlukan usaha terus-menerus semua potensi bangsa untuk merawatnya dengan penuh dedikasi serta komitmen keislaman dan keindonesiaan.

\section{Penutup}

Pribumisasi Islam akan terus berlangsung dalam suatu dialektika masyarakat dengan percepatan perubahan baik secara kualitatitf maupun kuantitatif. Ini berarti diperlukan keterlibatan elit-elit intelektual yang memerankan perantara budaya sehingga pribumisasi Islam berjalan tanpa perselisihan berarti. Dengan sikap keterbukaan yang kritis, elit-elit intelektual Muslim akan memberikan tanggapan yang tepat dan memberikan konsep-konsep utama tentang bagaimana hubungan Islam dan budaya Jawa diletakkan sehingga menghasilkan sinergi.

Islam dan budaya Jawa telah mengalami proses interaksi yang panjang. Keduanya telah saling belajar dan menghargai. Budaya Jawa telah memerankan diri sebagai "komplementer" bagi visi Islam tentang rahmatan lil-ālamīn. Di sisi lain, Islam telah tampil dengan sangat efektif di Nusantara karena memerhatikan unsur-unsur lokal sebagai sarana penjabaran operasional universalitas ajarannya. Dengan argumen ini, Islam telah menyatakan dirinya tepat dengan ruang dan waktu, termasuk dengan nilainilai Nusantara, khususnya nilai-nilai Jawa.

Karena itu, Islam bukan ancaman bagi nilai-nilai Jawa. Sebaliknya, budaya Jawa bukan pula ancaman bagi Islam. Justru dengan titik-titik taut nilai univeersal yang dimiliki keduanya, maka konsep rahmatan lil-'alamin yang dengannya Nabi Muhammad saw diutus menemukan maknanya secara baik. Di sinilah pribumisasi Islam dalam konteks budaya Jawa dapat dipertanggungjawabkan secara teologis, sosiologis, dan filosofis.

Tetapi pribumisasi Islam di tubuh budaya Jawa tidak berhenti di titik ini. Keadaan ini harus beranjak ke titik yang lebih luas, yakni kepentingan integrasi bangsa. Hubungan Islam dan budaya Jawa yang sudah mengalami keakraban yang berani harus menjadi modal sosial bagi kokohnya integrasi bangsa. Ia harus menjadi semen perekat bagi jiwa kesatuan dan persatuan bangsa yang ditopang oleh jiwa-jiwa manusia Indonesia. Suku-suku, budaya, dan nilai-nilai Islam selanjutnya menjadi puncak-puncak peradaban bangsa Indonesia. Yang dimaksud nilai-nilai Islam di sini adalah nilai-nilai Islam yang sudah diikatkan pada nilai-nilai lokal sehingga berjalan efektif dan relevan dengan nilai-nilai keadaban masyarakat. 


\section{Daftar Pustaka}

Abdullah, Irwan. "Kondisi Sosial yang Dibayangi Disintegrasi Tanpa Ujung" dalam Ninok Leksono (ed.), Indonesia Abad XXI Di Tengah Kepungan Perubahan Global. Jakarta: Penerbit Kompas, 2000, h. 4850 .

Adonis, al-Thābit wa al-Mutahawwil: Bahthun fì al-Ittib à', wa al-Ibda' Ind al-'Arab, (1) al-Ușūl, cet. Ke-5. Beirut, Libanon: Dār al-Fikr, 1986.

Chodjin, Achmad. Sunan Kalijaga: Mistik dan Makrifat. Jakarta: Penerbit Serambi, 2013.

Dale, S. F. Islamic Society and the South Asian Frontier: The Mappilas of Malabar 1498-1922. London: Oxford University Press, 1980.

Dhofir, Zamakhsari. Tradisi Pesantren: Studi tentang Pandangan Hidup Kyai. Jakarta: LP3ES, 1982.

Drake, Christine. National Integration in Indonesia: Pattern and Policies. Honolulu: University of Hawai Press, 1989.

Eliade, Mircea. The Myth of the Eternal Return, Cosmos and History. New Jersey: Princeton University Press, 1991.

Fakhry, M. A Short Introduction to Islamic Philosophy, Theology and Mysticism. Oxford: Oneword, 1997.

Geertz, Clifford. The Religion of Java. Chicago: The University of Chicago Press, 1960.

Groeneveld, W. P. Historical Notes on Indonesia and Malaya: Compiled From Chiness Sources. Jakarta: C. V. Bhatara, 1960.

Gusmian, Islah. Tafsir Alquran Nusantara: Dari Tradisi, Wacana, Hingga Relasi Kuasa. Yogyakarta: Pustaka Marwa, 2005.

Halkin, Abraham S. "The Judeo-Islamic Age, The Great Fusion" dalam Leo W. Schwarz, ed., Great Ages and Ideas of the Jewish People (New York: The Modern Library, 1956).

Hooker, MB. Islam Mazhab Indonesia: Fatwa-Fatwa dan Perubahan Sosial, terj. Iding Rosyidin Hasan. Jakarta: Penerbit Teraju, 2002.

Kartodirjo, Sartono. 700 Tahun Majapahit (1293-1993). Surabaya: Dinas Pariwisata Propinsi Daerah Tingkat I Jawa Timur, 1997.

Koentjaraningrat. Metode-Metode Antropologi Dalam Penyelidikan Masyarakat dan Kebudayaan di Indonesia. Jakarta: Penerbit Universitas, 1958. 
Maarif, Ahmad Syafii. Studi Tentang Percaturan dalam Konstituante: Islam dan Masalah Kenegaraan. Jakarta: LP3ES, 1985.

Madjid, Nurcholish. Islam Kemodernan dan Keindonesiaan. Bandung: Penerbit Mizan, 1987.

. "In search of Islamic Root For Modern Pluralism: The Indonesian Experience" dalam Mark R. Woodward, Toward A New Paradigm: Recent Developments in Indonesian Islamic Thought (Tempe, Arizona: Arizona State University, 1996).

Mulyana, Selamet. Runtuhnya Kerajaan Hindu-Jawa dan Timbulnya NegaraNegara Islam di Nusantara. Yogyakarta: LKiS, 2005.

Noer, Deliar. Gerakan Modern Islam di Inonesia 1900-1942. Jakarta: LP3ES, 1996, cet. Ke-8.

Qadir, C.A. Philosophy and Science in the Islamic World. London: Croom Helm, 1988.

Ricklefs, M. C., "Six Centuries of Islamization in Java" dalam Nehemia Levtzion (ed.), Conversion to Islam (New York: Holmes and Meier Publisher, Inc.: 1979.

Rosenthal, F. The Classical Heritage in Islam. London: Routledge and Kegan Paul, 1975.

Sihab, Alwi. Islam Inklusif: Menuju Sikap Terbuka dalam Beragama. Bandung: Mizan, 1999.

Soeratman, Darsiti. Kehidupan Dunia Keraton Surakarta 1830-1939. Yogyakarta: Yayasan Untuk Indonesia, 2000.

Stange, Paul. Politik Perhatian: Rasa Dalam Kebudayaan Jawa. Terj. Tim LKiS. Yogyakarta: LKiS, 1998.

T. King, Victor \& William D. Wilder. The Modern Anthropology of SouthEast Asia. Routledge Curzon, 2003 dan John R. Bowen "The Form Culture Takes: A State-of-the field essay on the Anthropology of Southeast Asia", The Journal of Asian Studies, 54: 1047-1078.

Toynbee, Arnold J. A. Study of History. London, New York, Toronto: Oxford University Press, 1956, 7th Edition, Vol. II.

Wahid, Abdurrahman. "Pribumisasi Islam" dalam Muntaha Azhari dan Abdul Mun'im Shaleh (edit.). Islam Indonesia Menatap Masa Depan. Jakarta: P3M, 1989.

Woodward, Mark R. Islam Jawa: Kesalehan Normatif Versus Kebatinan. Terj. Khairus Salim. Yogyakarta: LKiS, 1990. 
Pribumisasi Islam dalam Konteks Budaya Jawa dan Integrasi Bangsa

Zoetmoelder, P. J. Kalangwan: A Survey of Old Javanese Literature. The Hague: Martinus Nijhoff, 1974.

Mudhofir Abdullah, IAIN Surakarta, mudhofir1527@gmail.com

90 | INDO-ISLAMIKA, Volume 4, Nomor 1, Januari-Juni, 2014 